\title{
Pharmaceutical Modification of Kasisadi Churna to Varti and its Physicochemical Analysis
}

\author{
Research Article
}

\section{Pooja B $^{1 *}$, Govinda Sharma K², Vinay R Kadibagil ${ }^{3}$}

1. PG Scholar 2. Associate professor 3. HOD, Department of Rasashastra and Bhaishajya Kalpana, Sri Dharmasthala Manjunatheshwara College of Ayurveda and Hospital, Hassan, Karnataka.

\begin{abstract}
Background: Kasisadi churna is a yoga (formulation) mentioned for treatment of kaphaja yoni vyapath (vulvo vaginal candidiasis) which is applied as lepa along with honey. But the administration of the drug through vaginal route in this form is highly discomforting. Modification of a dosage form is essential for the enhancement of efficacy, acceptability of the product and shelf life. Materials and Methods: Varti is prepared from the drugs of kasisadi churna in three methods, bhavana method (KV1), gudapaka method (KV2) and modified method (KV3) with the addition of cocoa butter as base. The prepared samples were tested for analytical parameters. Result and Discussion: Kasisadi churna can be easily modified into varti form. Preparation of KV2 was easy, gives more yield in less time and better in organoleptic features and disintegration time compared to KV1 and KV3. Conclusion: The results of the pharmaceutical and analytical study can be considered as the preliminary standards for the preparation of Kasisadi Varti.
\end{abstract}

Key Words: Kasisadi churna, Varti, Samskara, Modification, Analysis, Yoni vyapath.

\section{Introduction}

Samskara (transformation) is the process of modification of guna (properties) of a given substance which is responsible for conversion of a raw material into medicine. There are several samskara mentioned in ayurveda like toya sannikarsha (processing with water), agni sannikarsha (processing with fire), shoucha (cleansing), mantha (churning), desha (place), kala (time), vasana (processing with proximity), bhavana (trituration)(1). The panchavidha kashaya kalpana known as primary preparations of bhaishajya kalpana are modified into secondary dosage forms like vati (tablet), varti (suppositories), avaleha (semisolid dosage form), sneha kalpana and other such dosage forms for better shelf life, easy administration and palatability.

Kasisadi churna is a yoga mentioned for treatment of kaphaja yoni vyapath which is applied as lepa along with honey(2). But the administration of the drug through vaginal route in this form is highly discomforting. Modification of a dosage form is essential for the enhancement of efficacy, acceptability of the product and shelf life. When compared to churna kalpana, varti are having more shelf life and are easily administered. Hence in this work, kasisadi churna was modified into varti form.

\section{* Corresponding Author:}

\section{Pooja B}

PG scholar

Department of Rasashastra and Bhaishajya Kalpana,

Sri Dharmasthala Manjunatheshwara College of

Ayurveda and Hospital, Hassan, Karnataka, India

Email Id: anu.pooja93@gmail.com
Varti kalpana is derivative of vati kalpana(3). Among the 7 types of varti, yoni varti is that mentioned for gynecological problems. It is designed in such a way that after insertion into vaginal canal they will either dissolve or disintegrate to release the medicaments (4). Varti can be prepared by classical methods like gudapaka or bhavana. In this study it was prepared by classical methods and by modified method with addition of cocoa butter as base.

\section{Materials and Methods}

The work was carried out in two steps

\section{Pharmaceutical study}

Kasisadi varti was prepared in three methods Bhavana (KV1), Gudapaka (KV2), Modified method (KV3)

\section{Analytical study \\ The prepared samples were analyzed to develop preliminary standards}

\section{Pharmaceutical study includes:}

A.Drug collection and authentication

B.Shodhana of Kasisa and Sphatika

C.Preparation of varti in three methods

\section{Drug collection and authentication}

Drugs required were collected from local vendor. The herbal drugs were authenticated from the experts of Dravya Guna. The mineral ingredients were authenticated from the experts of Rasashastra and Bhaishajya Kalpana. Table 1 gives the list of ingredients and quantity taken. 
Pooja B et.al., Pharmaceutical Modification of Kasisadi Churna to Varti and its Physicochemical Analysis

Table 1: Ingredients and their proportions

\begin{tabular}{r|l|l|l|l|l|l} 
S.N & Name of drug & Botanical Name/ English name & Part used & $\begin{array}{l}\text { Quantity } \\
\text { KV1 }\end{array}$ & $\begin{array}{l}\text { Quantity } \\
\text { KV2 }\end{array}$ & $\begin{array}{l}\text { Quantity } \\
\text { KV3 }\end{array}$ \\
\hline 1 & Kasisa & Ferrous sulphate & Whole & $50 \mathrm{gm}$ & $15 \mathrm{gm}$ & $50 \mathrm{gm}$ \\
\hline 2 & Haritaki & Terminalia chebula Retz. & Fruit & $50 \mathrm{gm}$ & $15 \mathrm{gm}$ & $50 \mathrm{gm}$ \\
3 & Vibhitaki & Terminalia bellerica Roxb. & Fruit & $50 \mathrm{gm}$ & $15 \mathrm{gm}$ & $50 \mathrm{gm}$ \\
4 & Amalaki & Emblica officinalis Gaertn. & Fruit & $50 \mathrm{gm}$ & $15 \mathrm{gm}$ & $50 \mathrm{gm}$ \\
5 & Sphatika & Potash alum & Whole & $50 \mathrm{gm}$ & $15 \mathrm{gm}$ & $50 \mathrm{gm}$ \\
6 & Jambu & Syzyigium cumini Skeels. & Seed coat & $50 \mathrm{gm}$ & $15 \mathrm{gm}$ & $50 \mathrm{gm}$ \\
7 & Amra & Magnifera indica L. & Seed coat & $50 \mathrm{gm}$ & $15 \mathrm{gm}$ & $50 \mathrm{gm}$ \\
8 & Dhataki & Woodfordia fruticosa Kurz. & Flower & $50 \mathrm{gm}$ & $15 \mathrm{gm}$ & $50 \mathrm{gm}$ \\
\hline 9 & Jala & Water & Whole & $3150 \mathrm{ml}$ & $100 \mathrm{ml}$ & $1250 \mathrm{ml}$ \\
10 & Guda & Jaggery & Whole & - & $240 \mathrm{gm}$ & - \\
11 & Cocoa butter & Theobroma oil & Whole & - & - & $40 \mathrm{gm}$
\end{tabular}

\section{Shodhana}

Prior to preparation of Varti, Shodhana of Kasisa (Ferrous sulphate) and Sphatika (Potash alum) were done.

\section{Kasisa Shodhana(5)}

Ashuddha Kasisa was powdered in a khalva yantra(mortar and pestle). Then it was transferred into a tray and sufficient quantity of Bhringaraja Swarasa required to soak the powdered Kasisa was added. It was dried under sunlight till it became completely devoid of moisture.

\section{Sphatika Shodhana(6)}

Ashuddha Sphatika was powdered in a khalva yantra. It was taken in an inert vessel and fried till the moisture content is evaporated and Sphatika became white, light and brittle.

\section{Preparation of Varti}

Preparation of Kasisadi varti by Bhavana method (KV1)(7)

Ingredients of Kasisadi Varti (table 1) were taken in equal quantity and were pounded separately, sieved to obtain fine powders. They were mixed together and triturated along with water in a wet grinder. For Bhavana, the sufficient quantity of water to immerse the Churna was added. The mixture was subjected for continuous and cautious trituration. When the water was dried, it was considered as the completion of first Bhavana. As and when the contents dried, water was added and the quantity was noted. Total 7 days of Bhavana was given. The images of preparation are given in fig 1 .

\section{Preparation of Kasisadi varti by Gudapaka method (KV2)(7)}

Ingredients of Kasisadi Varti (table 1) were taken in equal quantity and were pounded separately, sieved to obtain fine powders and all powders were mixed. Guda (jaggery) was dissolved in $100 \mathrm{ml}$ of water and heated on low flame. Once melted, it was filtered to remove impurities. The filtrate was reheated on low flame till 2 thread consistency. While heating was continued, Churna (powders) was added little by little and mixed well. The mixture was continuously stirred, till the paka lakshana was obtained. Later the gas stove was turned off. The mixture was taken out of stove and left for cooling. Initially the mixture was rolled into Varti form with approximate length and diameter of index finger. As it cooled and hardened it was again taken in the mould and was pressed to obtain Varti of uniform size and shape. It was dried in shade and stored. The images of preparation are given in fig 2 .

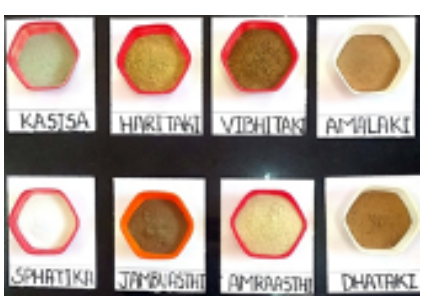

Fine powder of ingredients

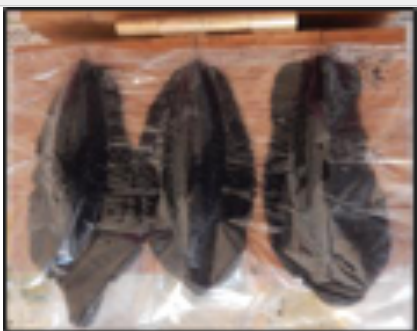

Pressed in mould

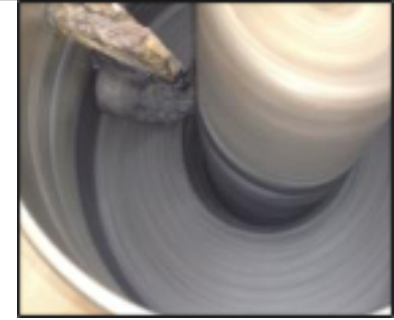

Trituration in wet grinder

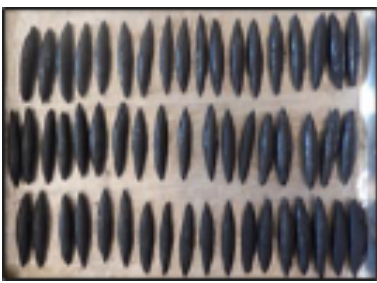

KV 1
Fig 1: Preparation of Kasisadi Varti by Bhavana Method - KV 1

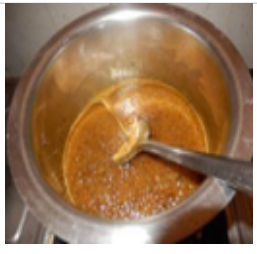

Gudapaka

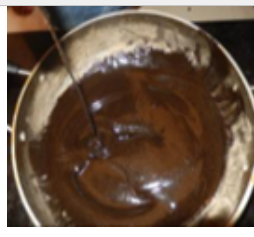

Homogenous mixture

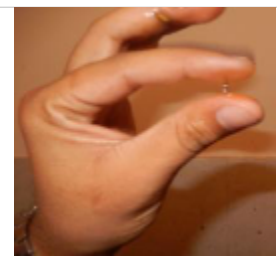

Tantumatvam

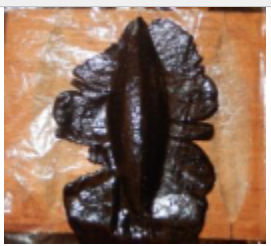

Pressed in mould

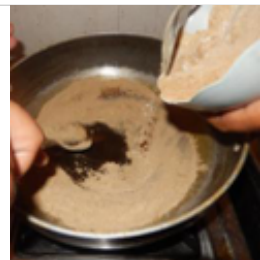

Addition of fine powders

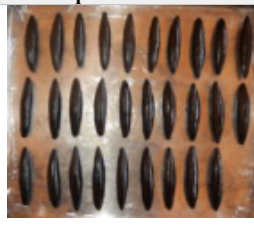

KV 2
Fig 2: Preparation fo Kasisadi Varti by Gupaka Method - KV 2 


\section{Preparation of Kasisadi varti by modified method} (KV3)

Ingredients of Kasisadi Varti (table 1) were taken in equal quantity. They were pounded separately, sieved to obtain fine powders. Cocoa butter was melted by indirect heating and mixed with the fine powders. Then the mixture was taken in wet grinder and water sufficient to immerse the Churna was added. The mixture was subjected for continuous and cautious trituration. As and when the contents dried, water was added and the quantity was noted. Two days Bhavana was given. After attaining Subhavita Lakshana, the mass was made into Varti form with the help of mould. Then it was dried and stored. The images of preparation are given in fig 3 .

Fig 3: Preparation of Kasisadi Varti by Modified Methods - KV3
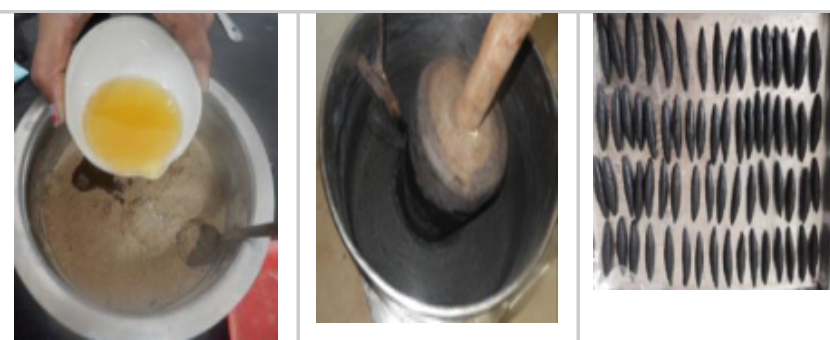

Addition of Cocoa Butter
Trituration in wet grinder

\section{Analytical Study}

The prepared samples were subjected to following tests as per the standard protocol given in CCRAS.

1. Organoleptic characters: Colour, odour and texture of the samples were examined.

2. Physical parameters (8-10): Hardness, Uniformity of weight, Disintegration time, Friability

3. Physico-chemical parameters (11-15):

- Total Ash, Acid insoluble Ash, Alcohol soluble extractive, Water soluble extractive, Determination of $\mathrm{pH}$, Volatile oil estimation

- High performance thin layer chromatography (HPTLC)(16) : 1g of powdered Varti was extracted with $10 \mathrm{ml}$ of alcohol. $5 \mu \mathrm{l}$, and $10 \mu \mathrm{l}$ of the extract were applied on a pre-coated silica gel F254 on aluminum plates to a band width of $7 \mathrm{~mm}$ using Linomat 5 TLC applicator. The plate was developed in Toluene: Ethyl acetate: Formic acid (8: $1: 0.2$ ). The developed plates were visualized in UV 254, 366, after derivatisation with vanillinsulphuric acid and scanned under UV 254 and 366. $\mathrm{Rf}$ (Retention factor), colour of the spots and densitometric scan were recorded.

\section{Observations and Results}

\section{Result of Kasisa Shodhana}

$470 \mathrm{gm}$ of ashuddha kasisa was taken and $800 \mathrm{ml}$ of bringaraja swarasa was required for soaking of the drug.

It took 52 hours for complete drying and final obtained shuddha kasisa was $373 \mathrm{gm}$ and greenish white in colour.

\section{Result of Sphatika Shodhana}

$400 \mathrm{gm}$ of ashuddha sphatika was taken and time required for frying, till loss of moisture was 49 minutes.

$197 \mathrm{gm}$ of shuddha sphatika was obtained which was white in colour.

\section{Result of Pharmaceutical study}

The results are tabulated in table 2 .

Table 2: Result of pharmaceutical study

\begin{tabular}{|l|l|l|l|}
\hline Parameters & KV1 & KV2 & KV3 \\
\hline Quantity of drug taken & $400 \mathrm{gm}$ churna & $120 \mathrm{gm}-$ churna; $240 \mathrm{gm}-$ guda & $400 \mathrm{gm}$ churna \\
\hline Total quantity of water used & $3150 \mathrm{ml}$ & $100 \mathrm{ml}$ & $1250 \mathrm{ml}$ \\
\hline Total time of Bhavana/ time for paka & $261 / 2 \mathrm{hrs}$ & $1 \mathrm{hr} 55 \mathrm{mins}$ & $71 / 2 \mathrm{hrs}$ \\
\hline Obtained quantity & $760 \mathrm{gm}$ & $330 \mathrm{gm}$ & $892 \mathrm{gm}$ \\
\hline Difference & $360 \mathrm{gm}$ & $30 \mathrm{gm}$ & $452 \mathrm{gm}$ \\
\hline Gain/loss & $90 \%$ & $8.33 \%$ & $102.7 \%$ \\
\hline Number of Varti obtained & 74 & 29 & 94 \\
\hline Weight of all Varti after drying & $438 \mathrm{gm}$ & $330 \mathrm{gm}$ & $512 \mathrm{gm}$ \\
\hline
\end{tabular}

\section{Result of Analytical study}

Organoleptic characters: All three samples were black in colour with characteristic odour. KV1 and KV3 were hard on touch, where as KV2 was soft.

The results of physical, physico chemical parameters are tabulated in table 3 and results of HPTLC are tabulated in tables 4 to 6 and photo documentation shown in fig 4 .

Table 3: Results of standardization tests for KV1, KV2, KV3

\begin{tabular}{|c|c|c|c|}
\hline Parameter & Results $\mathbf{n}=\mathbf{3} \% \mathbf{w} / \mathbf{w}$ \\
\hline & KV 1 & KV 2 & KV 3 \\
\hline Hardness & 12 & 8 & 11.5 \\
\hline Uniformity of weight & $6 \mathrm{gm}$ & $12 \mathrm{gm}$ & $5 \mathrm{gm}$ \\
\hline
\end{tabular}


Pooja B et.al., Pharmaceutical Modification of Kasisadi Churna to Varti and its Physicochemical Analysis

$\mathbf{P h}$

Friability

Disintegration time(min)

Total Ash

Acid Insoluble Ash

Water soluble Ash

Alcohol soluble extractive value

Water soluble extractive value

2.32

$0.83 \%$

More than $45 \mathrm{~min}$

$12.97 \pm 0.17$

$5.52 \pm 0.00$

$5.80 \pm 0.00$

$10.01 \pm 0.01$

$39.36 \pm 0.01$

2.83

$0.67 \%$

$34 \mathrm{~min}$

$6.26 \pm 0.01$

$1.95 \pm 0.00$

$3.36 \pm 0.00$

$23.10 \pm 0.00$

$82.50 \pm 0.00$
2.43

$0.61 \%$

More than $45 \mathrm{~min}$

$11.45 \pm 0.23$

$4.48 \pm 0.01$

$4.99 \pm 0.00$

$17.46 \pm 0.00$

$40.13 \pm 0.00$

\section{Results of HPTLC}

Table 4: $\mathbf{R}_{\mathbf{f}}$ values of samples at short $\mathbf{U V}$

\begin{tabular}{|c|c|c|c|c|c|c|c|c|}
\hline \multicolumn{3}{|c|}{ Short UV (254nm) } & \multicolumn{3}{|c|}{ Long UV (366nm) } & \multicolumn{3}{|c|}{ After derivatisation } \\
\hline KV1 & KV2 & KV3 & KV1 & KV2 & KV3 & KV1 & KV2 & KV3 \\
\hline - & 0.06 (Green) & - & - & - & - & - & - & - \\
\hline - & - & - & - & 0.27 (F. blue) & - & - & - & - \\
\hline - & - & - & - & - & - & - & - & 0.33 (Purple) \\
\hline - & 0.38 (L. green) & - & - & - & - & - & - & - \\
\hline- & - & - & - & - & - & - & - & 0.42 (Purple) \\
\hline - & - & - & 0.44 (F. green) & - & 0.44 (F. green) & - & - & - \\
\hline- & - & - & 0.52 (F. blue) & 0.52 (F. blue) & 0.52 (F. blue) & - & - & - \\
\hline- & - & - & - & - & - & - & - & 0.95 (Purple) \\
\hline
\end{tabular}

-L- light; D-dark; F - fluorescent

Table 5: HPTLC densitometric scan at $254 \mathrm{~nm}$

\begin{tabular}{|c|c|c|c|c|c|c|c|c|}
\hline \multicolumn{3}{|c|}{ KV1 } & \multicolumn{4}{|c|}{ KV2 } & \multicolumn{3}{c|}{ KV3 } \\
\hline Peak & $\begin{array}{c}\text { Max } \\
\text { position of Rf }\end{array}$ & \% Area & Peak & $\begin{array}{c}\text { Max } \\
\text { position of Rf }\end{array}$ & \% Area & Peak & $\begin{array}{c}\text { Max } \\
\text { Position of Rf }\end{array}$ & \% Area \\
\hline 1 & 0.04 & 90.25 & 1 & 0.04 & 60.08 & 1 & 0.04 & 88.22 \\
\hline 2 & 0.09 & 1.53 & 2 & 0.10 & 19.83 & 2 & 0.09 & 2.15 \\
\hline Absent & 3 & 0.19 & 4.24 & Absent & & & & \\
\hline Absent & 4 & 0.45 & 8.78 & Absent & & & & \\
\hline 3 & 0.66 & 8.22 & 5 & 0.64 & 7.06 & 3 & 0.65 & 9.63 \\
\hline
\end{tabular}

Table 6: HPTLC densitometric scan at $366 \mathrm{~nm}$

\begin{tabular}{|c|c|c|c|c|c|c|c|c|}
\hline & \multicolumn{3}{|c|}{ KV1 } \\
Peak & $\begin{array}{c}\text { Max } \\
\text { position of Rf }\end{array}$ & \% Area & Peak & $\begin{array}{c}\text { KV2 } \\
\text { Max } \\
\text { position of Rf }\end{array}$ & \% Area & Peak & $\begin{array}{c}\text { KV3 } \\
\text { Max } \\
\text { Position of Rf }\end{array}$ & \% Area \\
\hline Absent & 1 & 0.02 & 2.55 & Absent & & & & \\
\hline 1 & 0.04 & 5.73 & 2 & 0.05 & 11.49 & 1 & 0.05 & 30.13 \\
\hline 2 & 0.07 & 2.19 & 3 & 0.08 & 8.35 & 2 & 0.08 & 4.42 \\
\hline Absent & 4 & 0.34 & 5.12 & Absent & & & & \\
\hline 3 & 0.54 & 13.64 & 5 & 0.54 & 6.79 & 3 & 0.55 & 18.34 \\
\hline 4 & 0.62 & 64.39 & 6 & 0.63 & 61.09 & 4 & 0.64 & 43.16 \\
\hline 5 & 0.75 & 5.79 & Absent & Absent & & & & \\
\hline 6 & 0.79 & 4.82 & 7 & 0.79 & 4.61 & 5 & 0.81 & 3.94 \\
\hline 7 & 0.89 & 3.43 & Absent & Absent & & & & \\
\hline
\end{tabular}

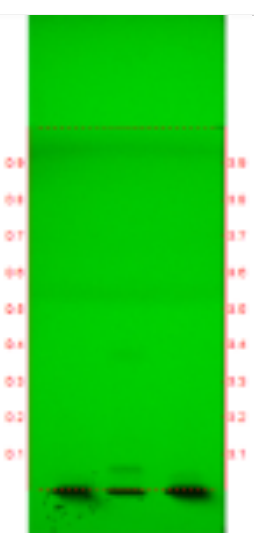

Short UV

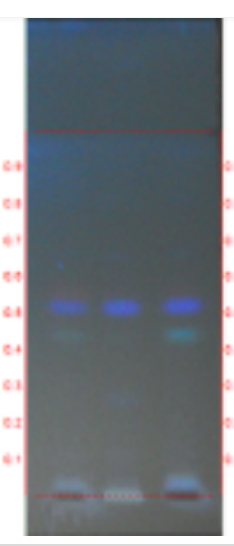

Long UV

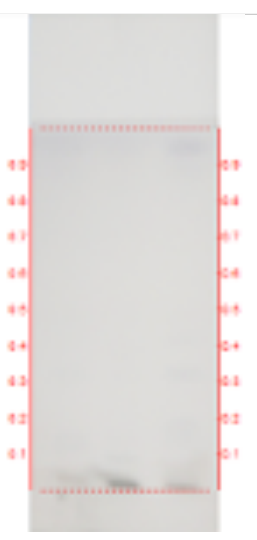

After derivatisation

Fig 4: HPTLC Analysis photo documentation of ethanol extract of KV1, KV2 and KV3 


\section{Discussion}

The method of Bhavana was adopted in the preparation of KV1, since it is one of the common methods of preparation of Vati/Varti. Here, based on anukta mana, bhavana dravya is considered as Jala. Initially fine powders of drugs were mixed homogenously and water required for its complete immersion was added. It was taken in wet grinder and trituration was done. For every one hour the contents got dried and $100 \mathrm{ml}$ of water was added. For each subsequent drying the quantity of water required was decreased. This may be because, continuous grinding makes particles more fine, thereby increasing the surface area of each particle and facilitating the easy and fast absorption of liquid media. Softness and smoothness was developed in the material in the later process of trituration which may be due to application of force and pressure during trituration. Fineness of particles were assured before subjecting to Bhavana as otherwise the grinding would be difficult and gaining proper consistency would not be possible. The spilling of drug was avoided to assure the correct method of trituration and to prevent wastage of material.

Gudapaka method is another commonly employed method for Varti preparation. The second method KV2 involved the preparation of jaggery syrup. Guda used was blackish brown in colour. This would be reason for the dark brown colour when Guda was dissolved in water. On heating, thick syrup obtained was may be due to evaporation of water portion and concentrating of Guda into the solution. The characteristic odour of Guda was appreciable on heating may be due to hydrolysis of its sugar content. Constant stirring was required in the preparation to avoid charring and sticking of jaggery to the vessel. Hence, stirring as continuous precaution is justifiable. The Gudapaka method was found easier and less time consuming compared to Bhavana method. But giving the required shape was quite difficult as it needed to be rolled into Varti form while it was hot. After cooling, the content become hard and is difficult to give shape.

The modified method involved the addition of cocoa butter to the fine powders of drugs. The cocoa butter is used widely as base in suppositories due to its properties. Because of its easy melting it may act as disintegrating agent. It was observed that softness and smoothness was developed in the material which may be due to application of force and pressure by trituration. The softness was comparatively more than that in KV1 it may be due the unctuous nature of cocoa butter. Subhavita Lakshana was attained earlier, may be due to high fat content in cocoa butter.

While preparing the three samples of Kasisadi Varti, the average size and circumference of Tarjani (index finger $-7 \mathrm{~cm} \times 5 \mathrm{~cm}$ ) was considered to follow as 'Tarjani Pramana' is specified for Yoni Varti. The quantity obtained from KV1 and KV3 method showed the gain of $9.5 \%$ and $16.3 \%$ respectively. It may be due to addition of water to ingredients for trituration. Whereas, in KV2, there was loss of $9.72 \%$, it may be due to Gudapaka leading to evaporation of water portion.

\section{Organoleptic characters}

In all the three prepared samples, the colour after drying was noted as black. To assess why black color was imparted, the drugs were mixed individually in water and in combination. When Kasisa and Amalaki were mixed together with water, the colour turned to black indicating some chemical reaction. Characteristic odour of Kasisa and Amalaki was appreciated in all three samples. The presence of metallic odour of Kasisa might be the reason for this. Odour of Guda was also appreciated in KV2. Texture was seen as granular in $\mathrm{KV} 1$ and KV3 which might be because of the fibrous nature of the plant origin drugs, while the texture was smooth in the KV2 as Guda was added. Another reason would be that Bhavana with water does not add much smoothness to the product unlike Guda. Guda being unctuous in nature impart more smoothness to the product.

\section{pH}

$\mathrm{pH}$ of all the three samples was acidic. $\mathrm{pH}$ of KV1 was comparatively more acidic probably because of the Amla Rasa of Kasisa(17) and Amalaki (18). KV2 and KV3 had addition of Guda and Cocoa butter respectively which made the drug less acidic compared to $\mathrm{KV} 1 . \mathrm{pH}$ as a measure of the hydrogen-ion activity is important from the standpoint of stability or physiological suitability. Since the $\mathrm{pH}$ of drug is almost near to the $\mathrm{pH}$ of vagina (3.8-4.5), it might help in better absorption.

\section{Hardness}

It is the resistance to attrition, abrasion, bending, breaking or crushing or impact strength. It is a property which is dependent on density and porosity of the material on one hand and pressure of the compression on the other. Hardness of three samples was within $12 \mathrm{~kg} / \mathrm{sq} / \mathrm{cm}$. While comparing the values, hardness of KV1 was found to be more, it may be due to the more number of Bhavana leading to more binding of particles of drug thereby resulting in more hardness, whereas in KV3 the percentage of cocoa butter in $10 \%$ and the Bhavana favored the binding and increase in intermolecular force. Hence the hardness is almost near to that of KV1 The percentage of Guda in KV2 is $66.66 \%$ and due to its soft nature the sample was less harder compared to other.

\section{Uniformity of weight}

The final product of each sample had different weight ( KV1-6gm, KV2-12gm, KV3-6gm) which may be due to difference in ingredients like in KV2, addition of Guda and in KV1 more quantity of water added for Bhavana would have lead to gain in weight respectively.

\section{Disintegration time}

It is the measure of time required under a given set of conditions for a group of Varti to disintegrate into 
particles. To determine the disintegration time of Varti, acidic $\mathrm{pH}$ was maintained to suit the vaginal $\mathrm{pH}$. It was observed that only KV2 disintegrated in 34 minutes and the sample KV1 and KV3 did not disintegrate even after 45 minutes. In KV1 the incorporation of subsequent triturations increased the intermolecular force thus resulting in delayed disintegration. In KV2 the presence of Guda showed the better disintegrating effect. In KV3 the presence of cocoa butter may be was not sufficient and the trituration has resulted in delayed disintegration. These values are not of much importance as it is not for oral medication.

\section{Friability}

This test is intended to determine the physical strength of drug. The friability of all the samples was within $1 \%$ (permissible limit).

\section{Total Ash}

The residue remaining after incineration is the ash content of the drug. It is used as a criterion for purity and identity of crude drugs. It showed that the KV1 $(12.97 \% \mathrm{w} / \mathrm{w})$, had more inorganic salts present in it. It was probably because it contained more percentage of Kasisa and Sphatika which are inorganic in nature. While KV2 (6.26 \% w/w) and KV3(11.45\% w/w contained Guda and cocoa butter respectively which were more organic in nature, thus reducing the percentage of Kasisa and Sphatika resulting in less inorganic component compared to KV1.

\section{Acid Insoluble Ash}

It is a part of total ash which is insoluble in dilute HCL. The acid insoluble of three samples being KV1- 5.52\%, KV2- $1.95 \%$, KV3- $4.48 \%$ shows the constituents which are insoluble in acid were more in $\mathrm{KV} 1$ and least in KV2.

\section{Alcohol soluble extractive}

This value is applied for the drugs which contain alcohol soluble constituents such as tannins, resins and alkaloids, thus helps to know active principles. The extractive value of KV2 (KV1-10.01\% $\mathrm{w} / \mathrm{w}, \mathrm{KV} 2-23.10 \% \mathrm{w} / \mathrm{w}, \mathrm{KV} 3-17.46 \% \mathrm{w} / \mathrm{w})$ is more may be due to presence of more of Guda which would have added bulk to the value. The KV3 contained Cocoa butter which is insoluble in alcohol, the content of KV1 included organic material and inorganic material like Kasisa and Sphatika which are insoluble in alcohol.

\section{Water soluble extractive}

The samples showed extractive value as KV1-39.36\%, KV2-82.50\%, KV3-40.13\%. The reason for this value would be same as above. Water soluble extractives indicate water soluble constituents such as tannins, sugars, plant acids and mucilage.

\section{HPTLC photo documentation}

HPTLC is a qualitative analysis method with major advancement of TLC principle with short time duration and better resolution. The prepared drugs were subjected to HPTLC fingerprinting at different wavelengths (254nm \& $366 \mathrm{~nm})$. This study reveals the chemical fingerprint profile of the test samples.

The $\mathrm{Rf}$, is related to the retention of the components and their consequent separation. It is defined as the ratio of time of an analyte is retained in the stationary phase to the time it is retained in the mobile phase. Hence, $\mathrm{Rf}=$ distance traveled by the component / distance traveled by solvent front. Rf value is characteristic for a particular compound in a particular solvent system and environmental conditions. In the present study three different samples of Kasisadi Varti (KV) were assessed at selected UV regions wavelength (at $254 \mathrm{~nm}$ and $366 \mathrm{~nm}$ ). The spots/peaks due to different components were documented. It acts as fingerprint of the used sample, which can be used as reference for the preparation of same kind of Varti.

At 254 nm: There were 3, 5 and 3 peaks in KV1, KV2 and KV3 respectively. It was observed that compounds with Rf $0.19(4.24 \%)$ and $0.45(8.78 \%)$ were absent in KV1 and KV3. The bands at different Rf value indicate the presence of particular active compounds.

Though KV2 had more percentage of Guda than other drugs, it has shown presence of more components.

At $366 \mathbf{~ n m ~ : ~ T h e r e ~ w e r e ~ 7 , ~} 7$ and 5 peaks in KV1, KV2 and KV3 respectively. Compound with Rf $0.02(2.55 \%)$ and $0.34(5.12 \%)$ was not detected in KV1 and KV3. Compound with Rf 0.75(5.79\%) was absent in KV2 and KV3. Compound with Rf 0.89(3.43\%) was absent in $\mathrm{KV} 2$ and KV3. More number of components are seen in $\mathrm{KV} 1$ and $\mathrm{KV} 2$, than in KV3.

\section{Conclusion}

Kasisadi Churna can be easily modified into Varti form. Preparation of Kasisadi Varti with Gudapaka (KV2) method is easy and gives more yield in less time. Analytical studies and HPTLC conducted on the study drug have helped to develop preliminary standards for Kasisadi Varti. Kasisadi Varti prepared by Gudapaka (KV2) method showed better organoleptic features and disintegration time.

\section{References}

1. Yadavji Trikamji Acharya. Charaka Samhitha of Agnivesha, Revised by Charaka and Dhridabala. Reprint. New Delhi; Chaukhambha Publications; 2014. 235p.

2. Shastri H S. Ashtanga Hridayam of Vagbhata. Reprint. Varanasi; Chaukhamba Sanskrit Sansthan; 2014. 900p.

3. Angadi R. A textbook of Bhaisajya Kalpana Vijnana. 1 $1^{\text {st }}$ ed. Varanasi; Chaukhamba Surbharati Prakshana; 2009. 217p.

4. Reddy R C. Bhaisajya Kalpana Vijnanam. 1 ${ }^{\text {st }}$ ed. Varanasi; Chaukhambha Sanskrit Bhawan; 1998. $317 \mathrm{p}$.

5. Acharya Y T. Rasarathna samucchaya of Vagbhata. Reprint. New Delhi; Meharchand Lachhmandas Publications; 1998. 50p. 
6. Mishra G S. Ayurveda Prakasha of Sri Madhava. $4^{\text {th }}$ ed. Varanasi; Chaukhambha Bharati Academy; 1994. 322p.

7. Angadi R. A textbook of Bhaishajya Kalpana Vijnana. 1st ed. Varanasi; Chaukhamba Surbharati Prakashan; 2009. 218p.

8. Anonymous. CCRAS, Laboratory Guide for the Analysis of Ayurveda and Siddha Formulation. 1 ${ }^{\text {st }}$ ed. New Delhi; Dept. Of Ayush Ministry of health and Family Welfare. Govt of India; 2010. 66p.

9. Anonymous. CCRAS, Laboratory Guide for the Analysis of Ayurveda and Siddha Formulation. $1^{\text {st }}$ ed. New Delhi; Dept. Of Ayush Ministry of health and Family Welfare. Govt of India; 2010. 63p.

10. Anonymous. CCRAS, Laboratory Guide for the Analysis of Ayurveda and Siddha Formulation. 1st ed. New Delhi; Dept. Of Ayush Ministry of health and Family Welfare. Govt of India; 2010. 65p.

11. Anonymous. CCRAS, Laboratory Guide for the Analysis of Ayurveda and Siddha Formulation. 1st ed. New Delhi; Dept. Of Ayush Ministry of health and Family Welfare. Govt of India; 2010. 28p.

12. Anonymous. CCRAS, Laboratory Guide for the Analysis of Ayurveda and Siddha Formulation. $1^{\text {st }}$ ed. New Delhi; Dept. Of Ayush Ministry of health and Family Welfare. Govt of India; 2010. 30p.
13. Anonymous. CCRAS, Laboratory Guide for the Analysis of Ayurveda and Siddha Formulation. 1st ed. New Delhi; Dept. Of Ayush Ministry of health and Family Welfare. Govt of India; 2010. 29p.

14. Anonymous. CCRAS, Laboratory Guide for the Analysis of Ayurveda and Siddha Formulation. 1 ${ }^{\text {st }}$ ed. New Delhi; Dept. Of Ayush Ministry of health and Family Welfare. Govt of India; 2010. 42p.

15. Anonymous. CCRAS, Laboratory Guide for the Analysis of Ayurveda and Siddha Formulation. 1 st $^{\text {st }}$ ed. New Delhi; Dept. Of Ayush Ministry of health and Family Welfare. Govt of India; 2010. 70p.

16. Anonymous. CCRAS, Laboratory Guide for the Analysis of Ayurveda and Siddha Formulation. 1 1 st ed. New Delhi; Dept. Of Ayush Ministry of health and Family Welfare. Govt of India; 2010. 92p.

17. Acharya Y T. Rasarathna samucchaya of Vagbhata. Reprint. New Delhi; Meharchand Lachhmandas Publications; 1998. 49p.

18. Anonymous. The Ayurvedic Pharmacopeia of India.Part1, Vol 1. 1 $1^{\text {st }}$ ed. Govt of India Ministry of Health and Family Welfare. Dept of AYUSH. Delhi; The Controller of Publications Civil lines; 200. 5-6p. 